〔器化 第 45 巻, 第 2 是, p. $68 \sim 74,1971$ ]

\title{
甘藷澱粉の内部油分に関する研究(第2 報)
}

\author{
磪位別溦粉について \\ 藤本滋生，永浜伴紀，篶江松雄

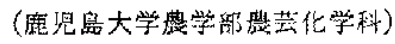 \\ 昭和 45 年 6 月 1 日受理
}

Studies on the "Fat by Hydrolysis" of the Sweet Potato Starch

Part II. The Difference among Tissues

By Shigeo Fujimoto, Tomonori Nagahama and Matsuo Kanie

Department of Agricultural Chemistry,

Faculty of Agriculture, Kagoshima University

\begin{abstract}
Starch samples of sweet potato (Norin No. 2) were prepared from the peel, cambium, and inner-tissue of smaller (av. wt, $24 \mathrm{~g}$ ) and larger (av. wt. $265 \mathrm{~g}$ ) tubers, harvested at the same time, respectively. The fatty acid components of "fat by hydrolysis" and some chemical and physical properties, such as particle size, iodine coloration, Brabender viscosity and $X$-ray diffraction were analyzed with these six samples.

Both amylose and fatty acid contents were higher in the peel starch, and low in the inner tissue starch. Within a variety, there would exist a general tendency that, the higher the fatty acid content of starch, the larger the proportion of palmitic acid, while that of oleic acid was smaller.

It was also confirmed that there were great differences about their properties among starches prepared from different tissues of larger tubers, while these differences were small among respective starches from smaller tubers, and the cambium starch of the larger tubers resembled in many respects closely to the smaller tuber starches.
\end{abstract}

(Received June 1, 1970)

\section{緒言}

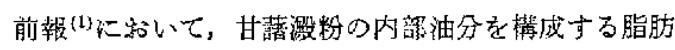
酸 (内部脂肪酸) をしらべ，その特徴括上び産地や品種

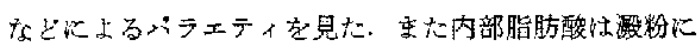
偶然にとり込をれた不純物ではなく，脂肪酸の種類心よ

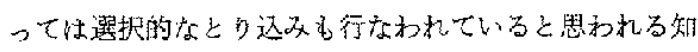
見を得た。

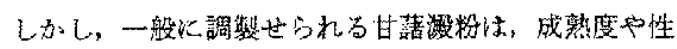
格の非常に異なる種々の檄子が混台されたものと考克ら

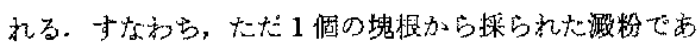

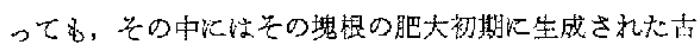
い粒子むあれば，掘取の直前に生成されたばかりの若い 粒子も含糔れているはずである。さらに塊根の大きさ，

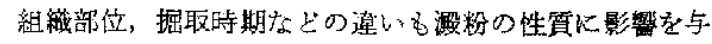

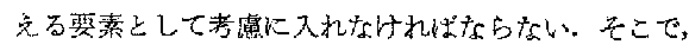
もしこれらの異なった修格の粒子を分別することがで光 れば，甘藷測粉の性質沈ついての上り正確な知見が得ら れるのではないかと思われる。

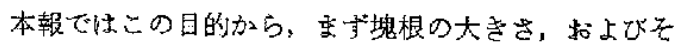
の部位による轻粉の一般的性質の違いを比较し，さら化 これと内部脂肪との関連性をしらべたので，その結果を 報告一娄。

\section{実 験 方 法}

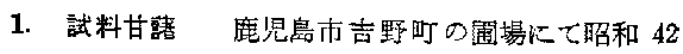
年 5 月 22 日以定植し，同年 10 月 24 日掘取った農林 2 号を用いた. 栽培日数は156日であるか゚，平年にくら 
ベて肥育状熊はやや悪く, 平均塊根重量柱約 $200 \mathrm{~g}$ で西った。

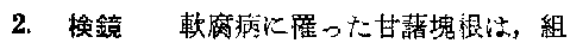
織の紐胞間結合が忡るくなり，容易汇単細胞状 に行離することか゚知られている(2)。そこでこれ

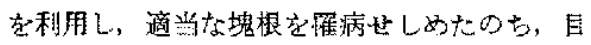

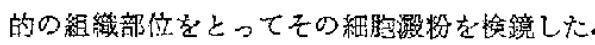

3. 粒度 日立光起查式粒度分有測定装臂 (PSA-2 型) によった。贸粉の比重はビクノメ 一ターに上る測定稘， $d=1.50$ をとり，水を分

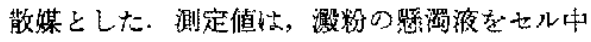

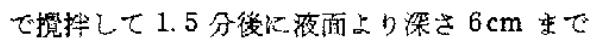

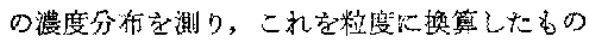

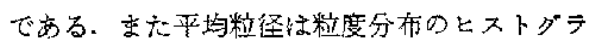
ムより計算した。

4. アミログラフィー ブラネンダービス

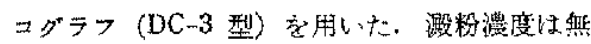
水物として $6.0 \%$ で， $\mathrm{pH}$ を7.0亿調整した。 これを1. $5^{\circ} \mathrm{C} /$ 分の昇 (降) 温速度て $30^{\circ} \mathrm{C}$ 上り $95^{\circ} \mathrm{C}$ をで温度を古げ， $95^{\circ} \mathrm{C}$ に 10 分間保持し たのち $50^{\circ} \mathrm{C}$ 降温し，この間の粘度を記録した。 ラムの回転速度佶 $75 \mathrm{rpm}$ とした。

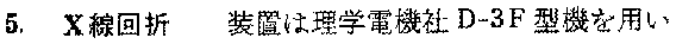

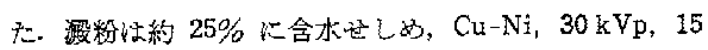
$\mathrm{mA}$ の条件で $2 \theta=3 \sim 30^{\circ}$ の籍囲意記録した，艺の他の 諸条件は檜作ら ${ }^{(3)}$ 汇準した。

6. ヨート显色值 試料滶粉は Schoch 法( 部油分を除去したものを用いた，溶解住 McCready ら(ま)

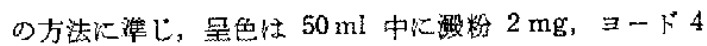
$\mathrm{mg}$ 、 ヨウ化カリウム $40 \mathrm{mg}$ の条件をとった，これを 1 夜放置後, 日立光電光度計 $(\mathrm{FPW}-4$ 型 $)$ 孝用いて $1 \mathrm{~cm}$ セル， $660 \mathrm{~m} \mu$ フィルターでの吸光度を測定した。

7. 内部脂肪酸 内部脂肪酸の抽出およびそのガス クロマトグラフィー(GLC) に上る定量住すべて前報(1) 核載の方法洋った。

\section{実験結果むよび考察}

\section{1. 塊根の部位による搌粉の比較およひ試料の調矮}

甘藷塊根の断面惊第1图に示すような組織構造である

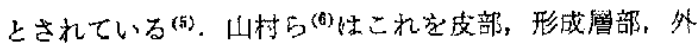
中心部，中心部の 4 新に牙割してそれぞれ謴粉を上り， 皮部の澱粉含是は少なく䊀子も小さいことなとを報告し

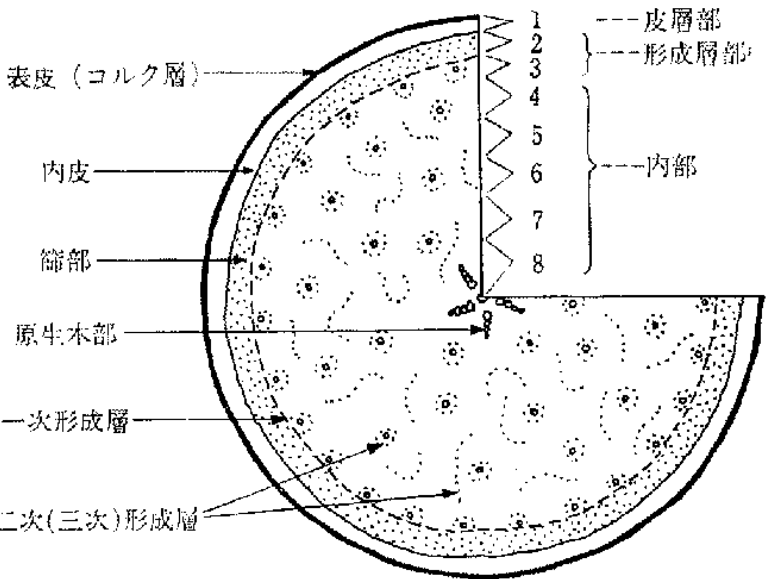

第 1 図世藷塊根断面図 ${ }^{(0)}$

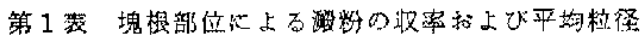

\begin{tabular}{lrrrrrrrr}
\hline 部 位* & 1 & \multicolumn{1}{c}{2} & \multicolumn{1}{c}{3} & \multicolumn{1}{c}{4} & 5 & 6 & 7 & 8 \\
\hline 収 萃**o & 8.9 & 19.8 & 19.3 & 20.2 & 19.1 & 17.8 & 18.3 & 16.8 \\
平均粒径 $\mu$ & 6.8 & 7.1 & 8.4 & 11.6 & 12.4 & 12.5 & 12.6 & 12.6 \\
\hline
\end{tabular}

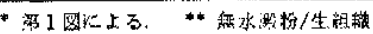

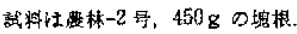

ている、著者らむこれにならい，重量 $450 \mathrm{~g}$ ，中央部直 径 $8 \mathrm{~cm}$ の塊根選んでこの中央部㕝約 $2 \mathrm{~cm}$ 厚さの輪

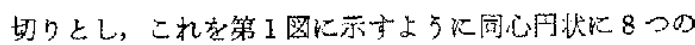
部分（1〜8）に分割した。この各分割部上り，是れそれ 家庭用ミ辛サ一を使って調製し太激粉の收率打よひ平均 糕径杜第 I 表化示すと和りであった。

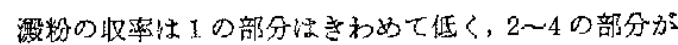

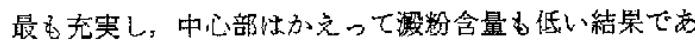

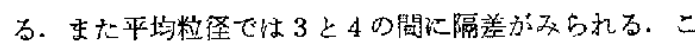
れらの結果を断面の組織構造と対比して考光ると，同心 円的火注皮層部 (1)，形成層部 $(2,3)$ ，内部 $(4 \sim 8)$ ， の3部位に区别するのが適当と思すれる、要たこ机らる 部位の代表的な細胞形態壮第 2 图のようなもので㭊っ

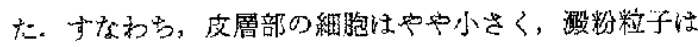
要ばらに存在して赫り，形成層部は小細胞が多く，任之

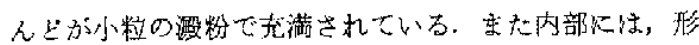
成屬部でみられるような小紐胞も混在するが，一般に細 胞估大形でり，敏粉粒子む大きい。しかしこれらの各 組織部位加ら分離した激粉粒には，第 3 图化示されるよ 与形態的な違いは見られない。

また適当な違った重量の塊根向㮯を選び，それ艺れを

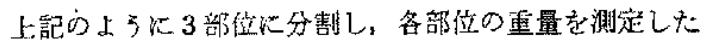




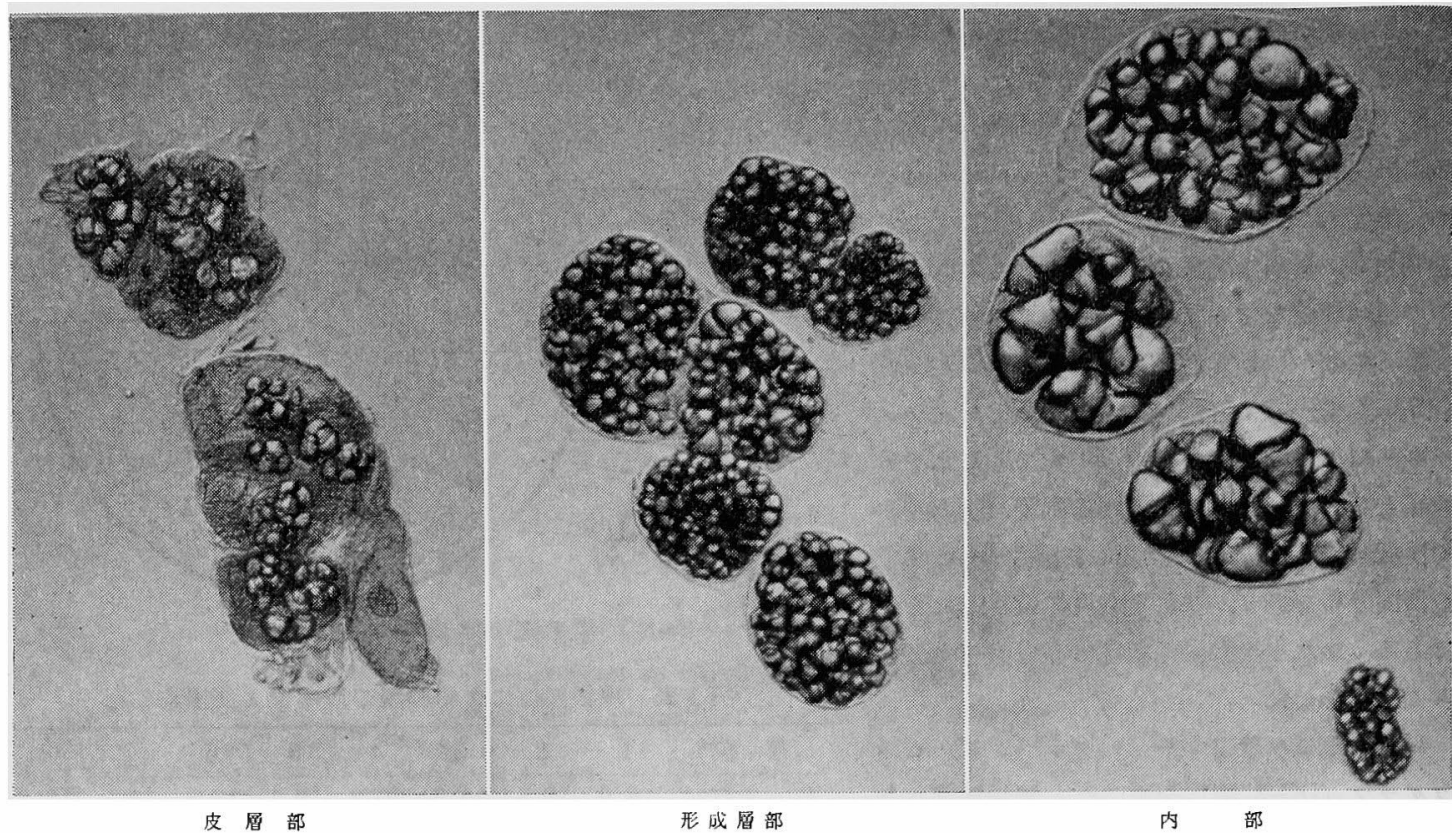

第 2 図組織別の細胞澱粉形態 $(\times 600)$

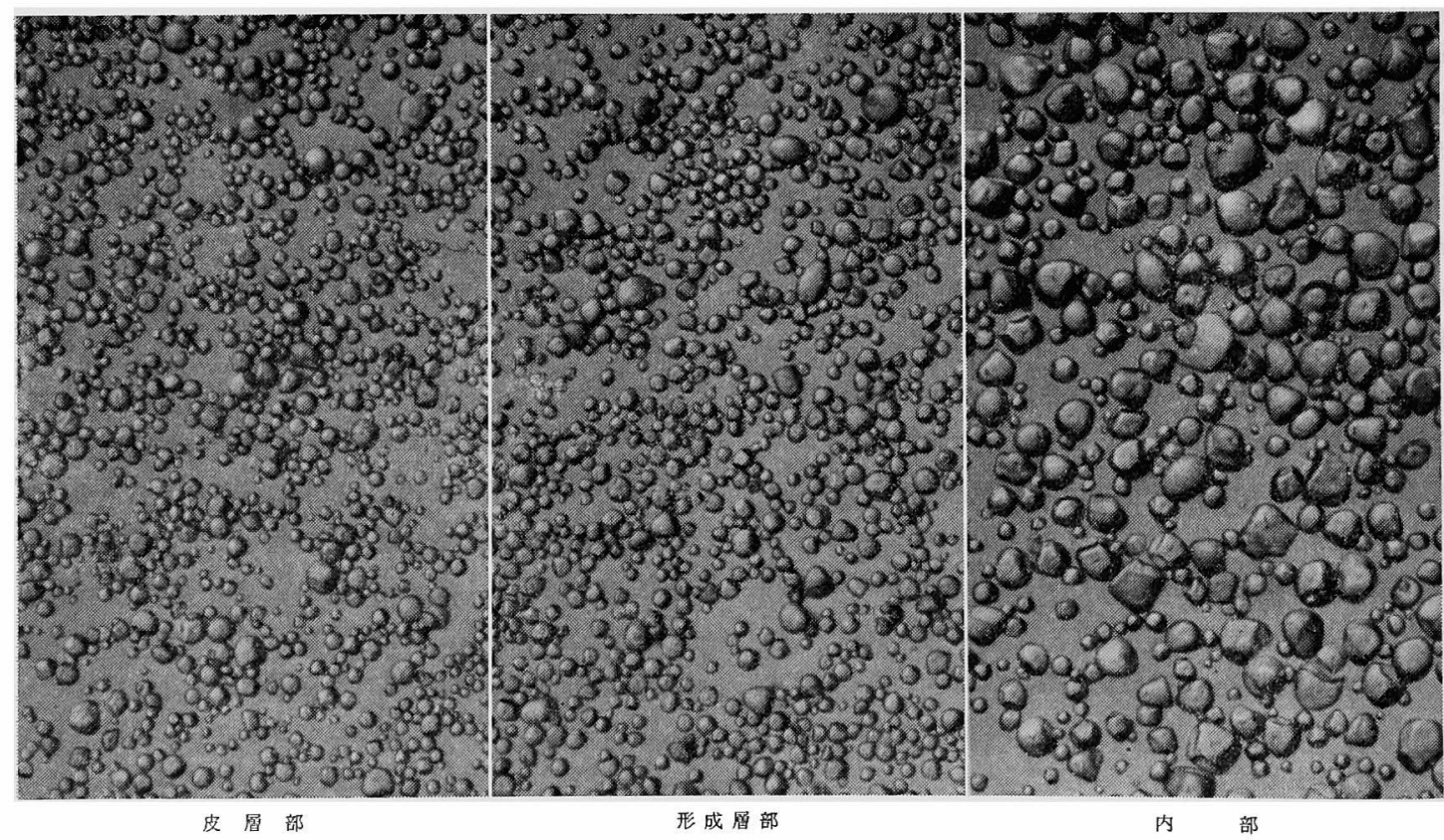

第3図組織別の澱 粉 粒子 (x600)

\section{ところ箩 4 図の結果を得た。}

これから，塊根の大きさとよって各部位に由来する澌 粉の比率も違ってくることがわかる. すなわち, 塊根が 小さい場合は皮層部の澱粉の割合が多いことになる、ま た前報でもふれたように, 同じ部位でも塊根の大きさに
よって澱粉の性質が違らことも予想されるので, 分別に 際しては部位とともに塊根の大きさも考虑し, 次のよ5 に行なった.すなおち, 試料甘諸の中から小塊根（平均 $24 \mathrm{~g}$ ) 約 450 個と大塊根（平均 $256 \mathrm{~g}$ ) 約 40 個を選び, それぞれを皮層部，形成層部，内部の 3 部位に分割して 


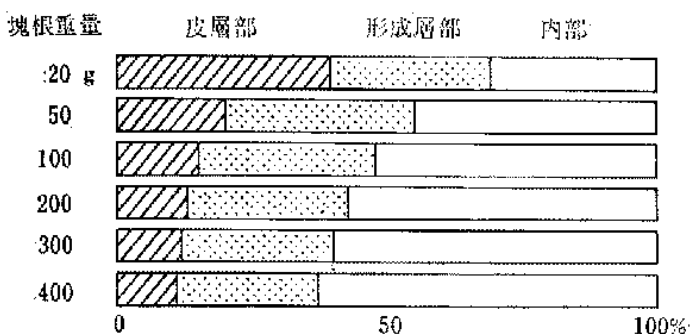

第 4 图 塊根の大きさ之缡位の绪合

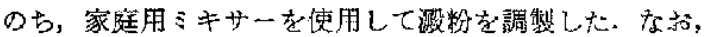
土肉は洀粉に対与る水の量を種々調節することによりく り返し分離せしめ，できるがり完全借去した。

\section{2. 级率および粗度}

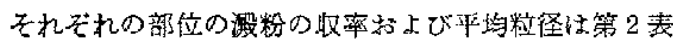

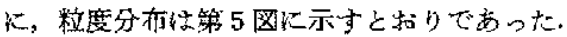

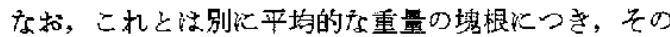

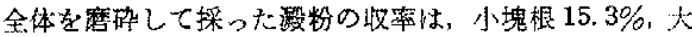
塊根 19.5\%であり，平均粒径は 9.5 凡およ゙ $11.9 \mu$

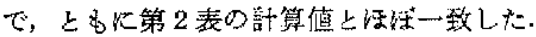

第 2 表 部位別澱粉の取染就よび平均粒经

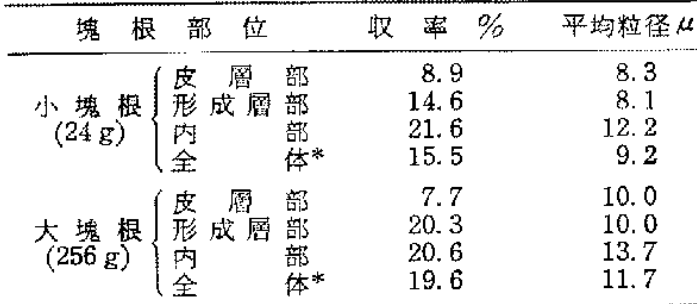

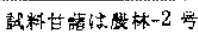

* 新算值
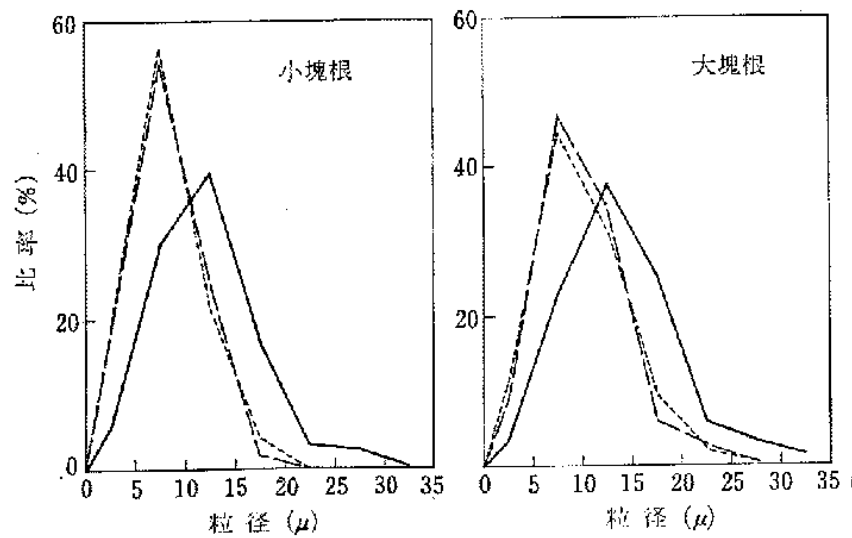

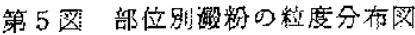

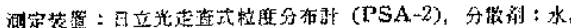

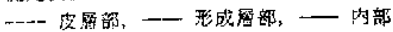
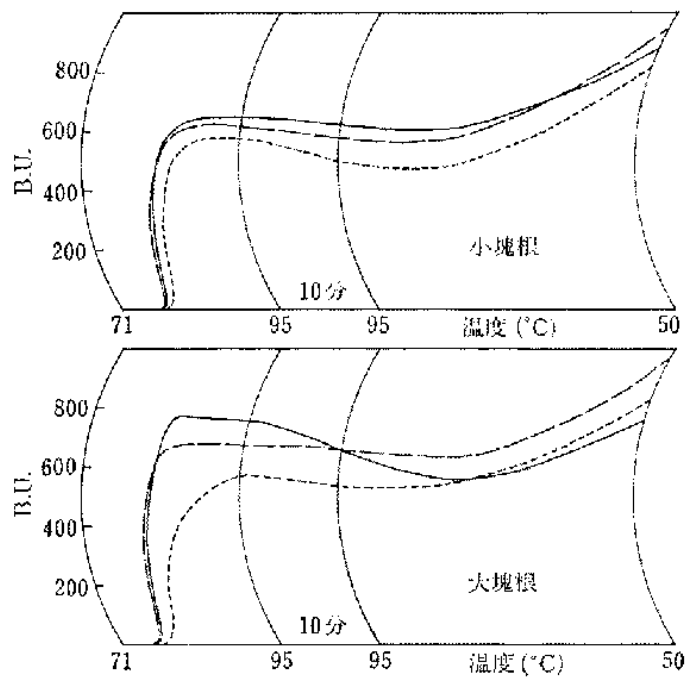

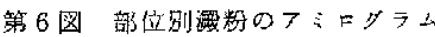

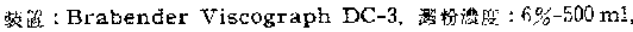

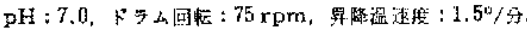

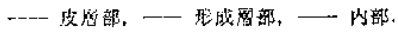

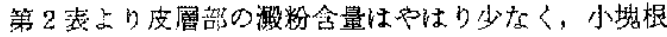

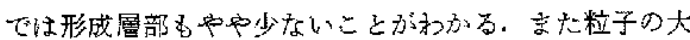

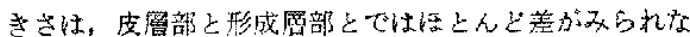

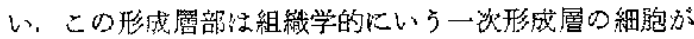
中心孛なしているので，比較的若い細胞が多いと思初れ，

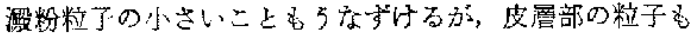

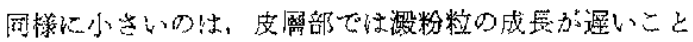

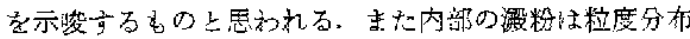

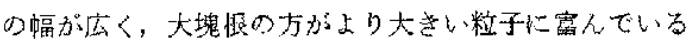

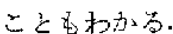

\section{3. アミログフム}

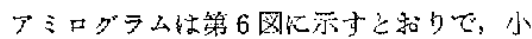

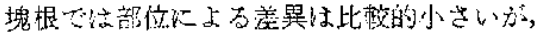

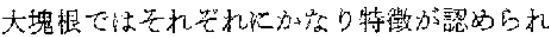

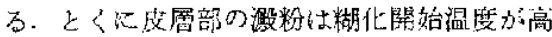

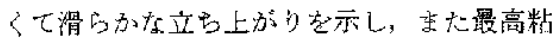

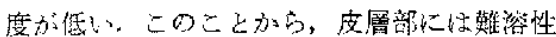
の澱粉方混在しているのではないると思机儿

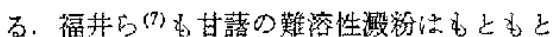

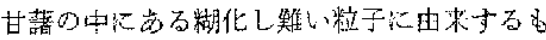
のであるう上推諭している。しかし大熄根の

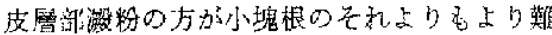

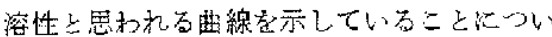
ては，塊根の肥大绊って難溶俚化するのわ, 
あるいは生成された環境の違い炕上るあのか明らかてな いこ扎にいてはさらに换討が必珐であ万う。

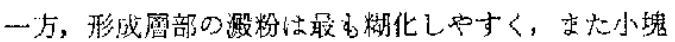

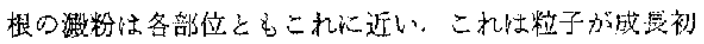
期の段階て小粒ですることな上共通しているためと思和 れる。また内䑙晸粉の粘度が高く、ブレークダウンが大 きい曲線は大型粒子の特致として説明される(8)。

\section{4. $\mathrm{X}$ 線回折}

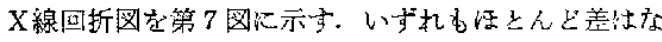

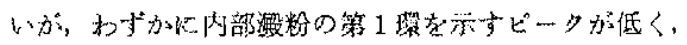
また第 4 環のaとbの差が接近してや中A型に近い回折

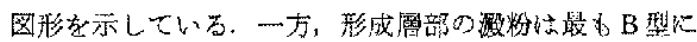
近いと判断される。一般に植物の種類を間わ方，澱粉粒

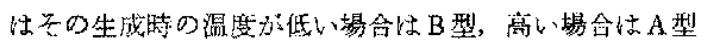

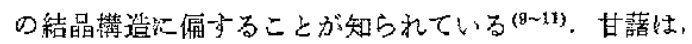
晚春から晩秋までの長期に啮って肥大る続りるので，内 部の瑖粉がA型に近いことは，これが夏期の高温時以成

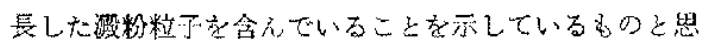

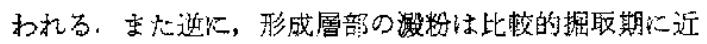

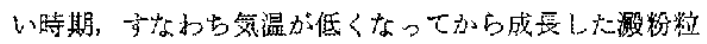
丁であるとい5ことができよ。

\section{5. ヨード量色缇および内部脂肪酸}

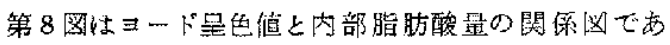
る. ヨート呈色俻は注ばアミロース含量に比例すると考

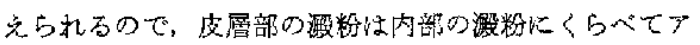
ミロースや脂肪酸がき和めて多いとい方る，アミログラ

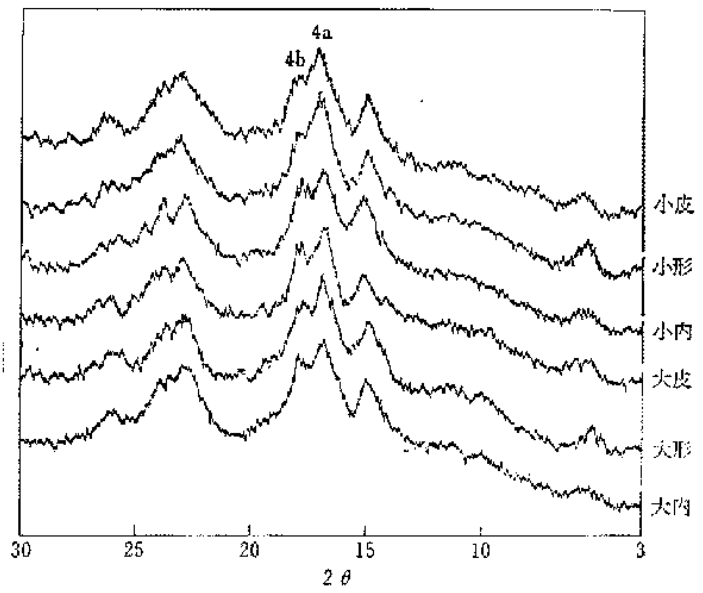

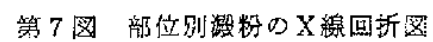

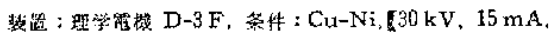

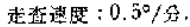

（侧：大内 $=$ 大塊根以部路烃）

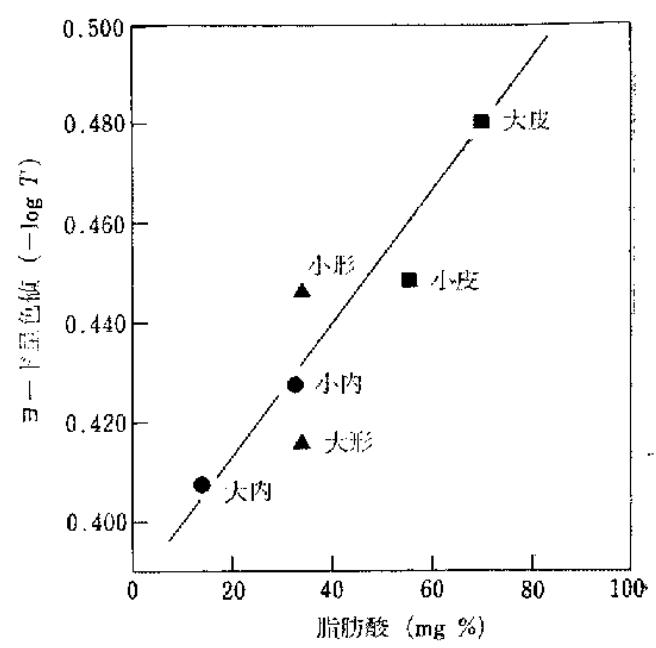

第 8 図 ヨ- 量色值上内部脂肪酸 (附：大内

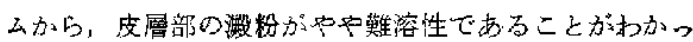
たが，これがアミロ一スや脂肪酸心富むこ上休，荒井 ら (12)の難浴性搌粉の分析結果とむ一致している。 また このグラフから，アミロース量と能肪酸量の関係は活ぼ 相関的であることが古かる。

次にこれらと粒子の大きさとの夙係をみると第 9 図か

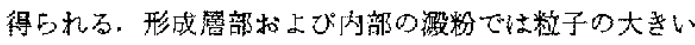
bのほ上゙アミロースや脂肪酸が少ない傎向があるか，皮

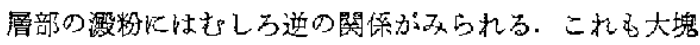
根の皮層部潵粉がより矆溶性であることの一因であると 思和れる。

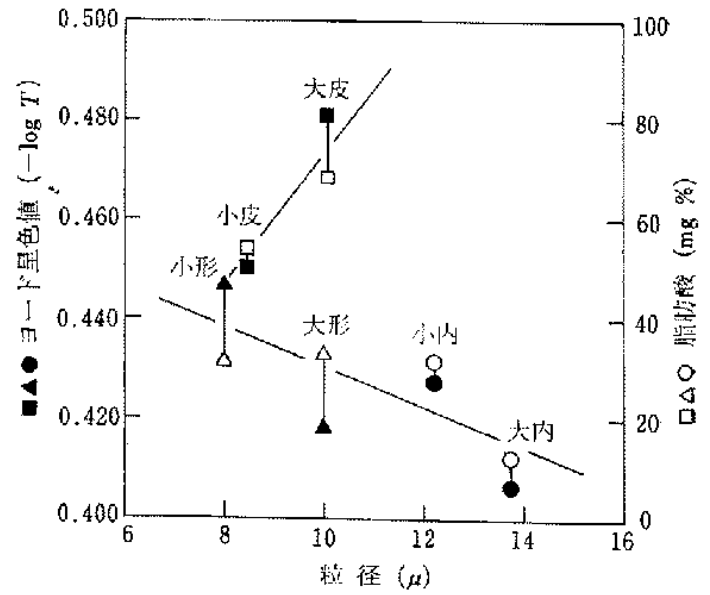

第9図ヨード是色隹, 内部脂肪酸, 粒径の関倸 （侧：大内 =大堍根内部繁枌） 
第 3 表 内部脂肪酸の組成割合（ガスクロマトダラフィー*）

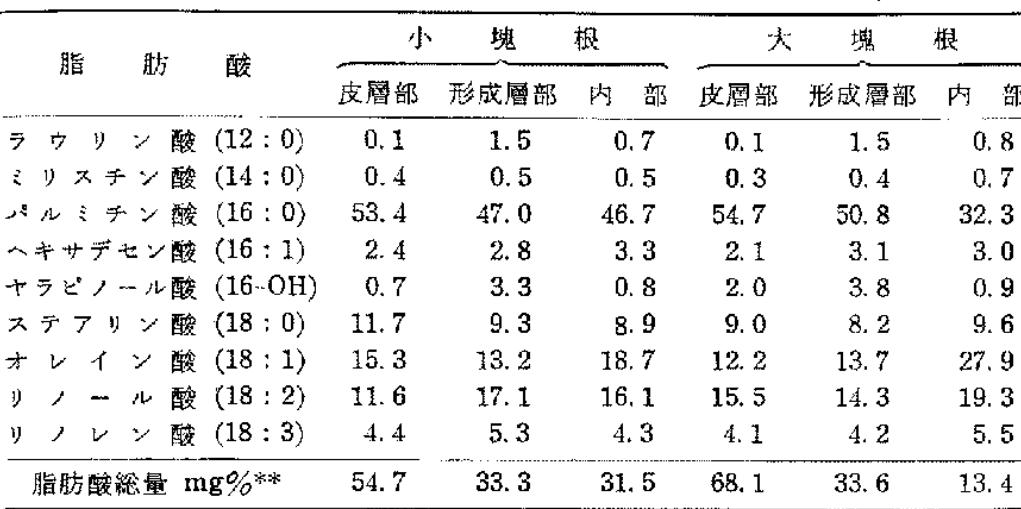

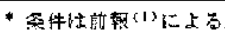

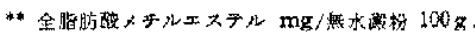

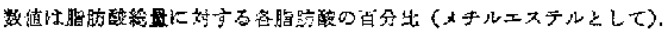

\section{6. 内部脂肪酸粗成}

次にこの内部脂肪垔の組成割合をガスクロマトグラフ イーでしらべ結果は第 3 表のと洛りであった。

各部位苏るい塊根の大小汇より，㐻部脂肪酸の総量 が違らばかかななと組成割合も少しずつ違らことが

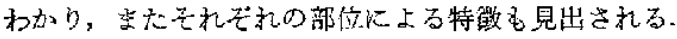

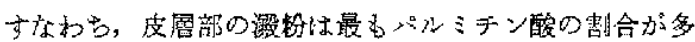

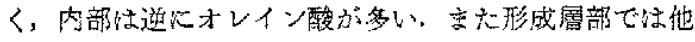
とくらべてラウリン酸やャラピノール酸の割合が多い. な和，前報(1)の市肘や品種别の澌粉間で怯，脂肪酸の多 いるのが相詨的にリノール酸に富んでいたが，第 3 表の

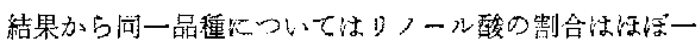
定であるといるる。

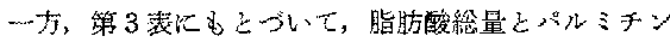

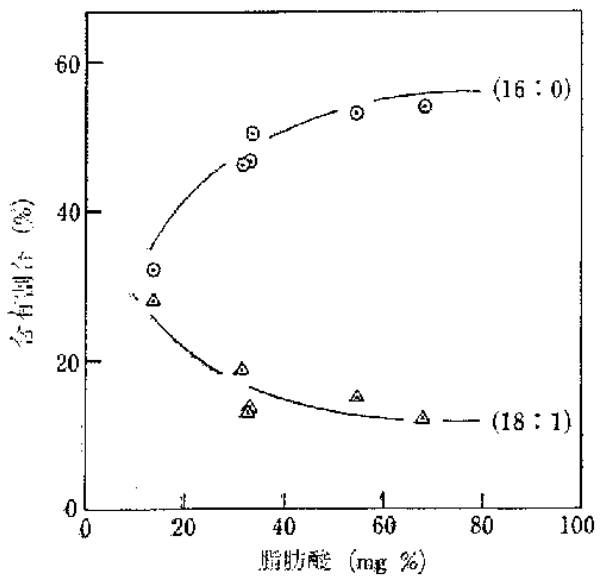

第 10 因 脂肪酸総量とパルミチン酸就よび オレイン酸の踓合
酸怙よびオンイン酸との関保 さグラフ化すると，筆10园 湆得られ，脂肪酸総量の多い ものはどンシキン酸の制合

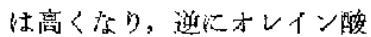
が纸くなっている。このこと から，脂肪酸総量と文の組成 割台との閣比相関的な関係

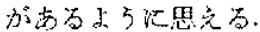

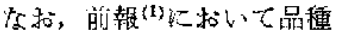

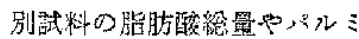
チン酸の割合なとが市販晸粉 飞比較して全般に低加ったが, これ性品種別詿料がいずれる

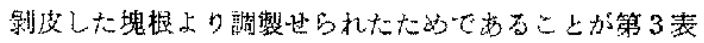
の結果より説明される。

\section{7. 稳 括}

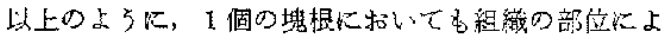

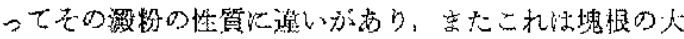
きさによっても左右されていることがわかった，度層部

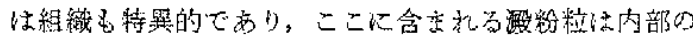
ものとは翼なった成長過程をつるものと思々れる。また

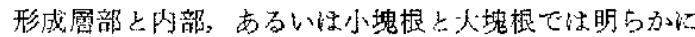

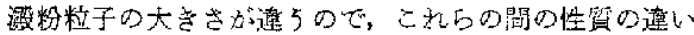

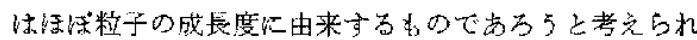
る. しかし，この点汇䦥してはX線回折把難溶性洀粉の

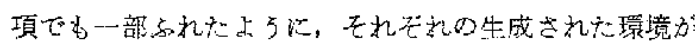

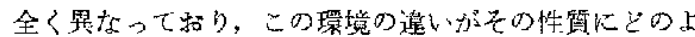

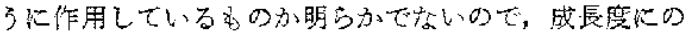

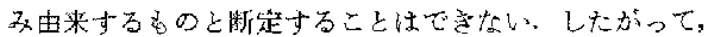

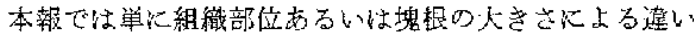

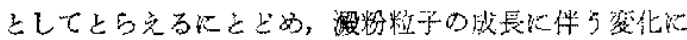
ついては改めて穘報で検討していきたい。

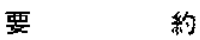

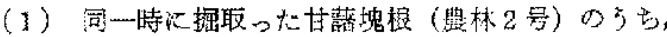
小塊根と大塊根を觉らび，それぞれ皮層部，形成罜部、

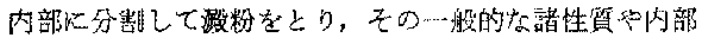
脂肪酸を比較した。

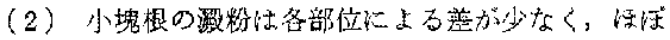
大塊根の形成圈部に近い性質を持つが，大塊根では部位

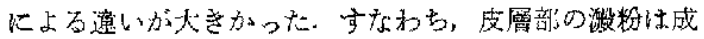




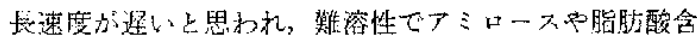

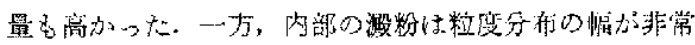

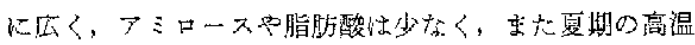

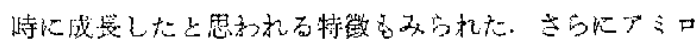

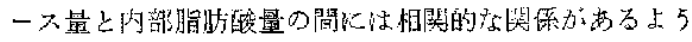
思机机。

(3) 各陚料以つに大内部脂肪酸の量の欢でなく， そ

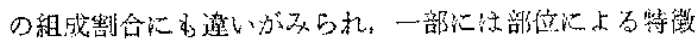

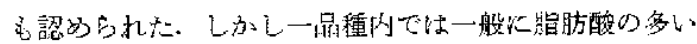

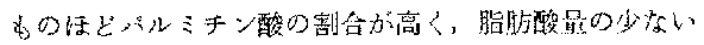
むのはオレイン酸心富上傾间があることから，脂肪滛の

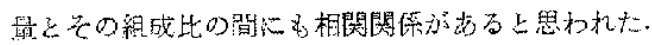

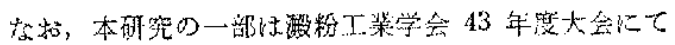
発表した。

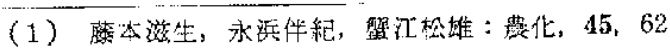
(1971).

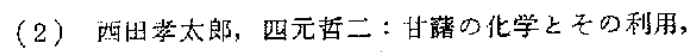
湖會畒虚，1948，p.158.

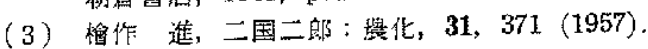

(4) R.M.McCready and W.Z. Hassid : J.Am. Chem. Soc., 65, 1154 (1943).

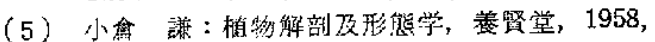
p. 107 .

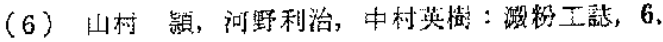
60 (1959).

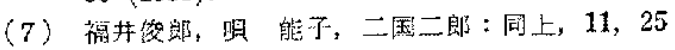
(1964).

（8）渡辺第二：同上，4，138（1957).

(9) S. Hizukuri, M. Fujii and Z. Nikuni : Nature, 192, 239 (1961).

（10）鈴木 裕，檜作 進，二国二郎：罢化，37，63 (1963).

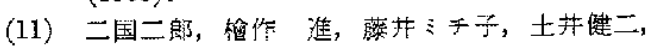

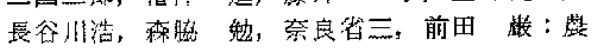
化, 37, 673 (1963).

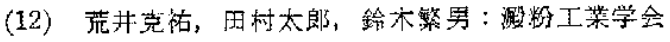
42 年慗大会 (1962). 